\title{
Worldwide Typology of Nearshore Coastal Systems: Defining the Estuarine Filter of River Inputs to the Oceans
}

\author{
Hans H. Dürr • Goulven G. Laruelle • \\ Cheryl M. van Kempen • Caroline P. Slomp • \\ Michel Meybeck • Hans Middelkoop
}

Received: 26 June 2009 /Revised: 17 January 2011 /Accepted: 24 January 2011 /Published online: 1 March 2011

(C) The Author(s) 2011. This article is published with open access at Springerlink.com

\begin{abstract}
We present a spatially explicit global overview of nearshore coastal types, based on hydrological, lithological and morphological criteria. A total of four main operational types act as active filters of both dissolved and suspended material entering the ocean from land: small deltas (type I), tidal systems (II), lagoons (III) and fjords (IV). Large rivers (V) largely bypass the nearshore filter, while karstic (VI) and arheic coasts (VII) act as inactive filters. This typology provides new insight into the spatial distribution and inherent heterogeneity of estuarine filters worldwide. The relative importance of each type at the global scale is calculated and types I, II, III and IV account for $32 \%, 22 \%, 8 \%$ and $26 \%$ of the global coastline, respectively, while $12 \%$ have a very limited nearshore coastal filter. As an application of this typology, the global estuarine surface area is re-estimated to $1.1 \times 10^{6} \mathrm{~km}^{2}$ instead of $1.4 \times 10^{6} \mathrm{~km}^{2}$ in earlier work.
\end{abstract}

Hans H. Dürr and Goulven G. Laruelle have contributed equally to this manuscript.

Electronic supplementary material The online version of this article (doi:10.1007/s12237-011-9381-y) contains supplementary material, which is available to authorized users.

H. H. Dürr $(\bowtie) \cdot$ H. Middelkoop

Department of Physical Geography, Faculty of Geosciences, Utrecht University,

Heidelberglaan 2, P.O. Box 80.115, 3508 TC, Utrecht,

The Netherlands

e-mail: h.durr@geo.uu.nl

G. G. Laruelle $\cdot$ C. M. van Kempen • C. P. Slomp

Department of Earth Sciences-Geochemistry,

Faculty of Geosciences, Utrecht University,

Utrecht, The Netherlands

M. Meybeck

UMR 7619 Sisyphe, Université Pierre et Marie Curie (Paris VI),

Paris, France
Keywords Coastal zone · Typology · Global assessment . Estuarine filter - Earth system analysis

\section{Introduction}

The coastal zone is the highly dynamic transition area where the land meets the ocean. It constitutes one of the most active interfaces of the biosphere (Gattuso et al. 1998) and provides important human ecosystem services (Kempe 1988; Crossland et al. 2003). Despite its limited surface area compared to the open ocean, the coastal zone plays an important role in the global cycling of many biogeochemically important elements. For example, it receives major inputs of terrestrial material, such as suspended sediments and nutrients in dissolved or particulate forms, through river and groundwater discharge and exchanges large amounts of energy and matter with the open ocean (Alongi 1998; Rabouille et al. 2001; Slomp and Van Cappellen 2004).

A large and increasing proportion of the global population lives in this domain, and this makes it one of the most perturbed areas and vulnerable to global changes such as land use modifications, urbanisation, sea level rise or climate change (Crossland et al. 2003). While many models exist to describe the biogeochemistry of estuaries and other coastal systems on a local and regional scale (Allen et al. 2001; Lohrenz et al. 2002; Moll and Radach 2003), the incorporation of the nearshore coastal zone into global oceanic models remains limited by resolution constraints. As yet, the spatially complex pattern of incoming riverine fluxes is commonly either simplified or ignored when defining boundary conditions of ocean general circulation models, by either combining the nearshore environment (or 'estuarine filter') with the distal shelf zone or treating it as a single, 
homogeneous reservoir with a single river input (Aumont et al. 2001; Da Cunha et al. 2007; Bernard et al. 2009).

But how is the coastal zone defined exactly? This depends on the point of interest. Oceanographers tend to use the term for the continental shelves as a whole (Smith and Hollibaugh 1993; Crossland et al. 2003) where the shelves are seen as a filter between the realm of rivers and other continental influences and the open ocean. The shelves are often approached as a system of several layers, with the first level being the transition zone between riverine (fresh) and marine waters, generally termed as 'estuaries' (Woodwell et al. 1973).

A large body of literature exists on definitions of the different types of nearshore coastal systems. These definitions are commonly based on their origin, geomorphology, dynamics, sediment balance, biogeochemistry or ecology (Elliott and McLusky 2002; Meybeck et al. 2004; Schwartz 2005; Meybeck and Dürr 2009). The most wellknown global scale 'coastal typology' established to date is the one of LOICZ (Talaue-McManus et al. 2003; Crossland et al. 2003; Buddemeier et al. 2008), which describes nutrient levels in individual coastal cells at $0.5^{\circ}$ latitudelongitude resolution. The types are derived from a statistical treatment of a large number of physical and morphological criteria combining terrestrial and marine realms and including human impacts (Gordon et al. 1996). The LOICZ typology is of great value for coastal zone biogeochemical flux assessments and is the only comprehensive, spatially explicit global scale effort we are aware of. However, the results are not easily used outside the context of analysis of groups of cells with similar characteristics (i.e. clusters), since at high resolution (e.g. $1 \mathrm{~km}$ ), cells along the coastline belonging to the same estuarine object, i.e. a bay or lagoon, can be attributed to different clusters (cf. Crossland et al. 2003, www.ozcoasts.org.au, accessed 30 September 2010).

Other typologies have been developed, but their geographical extent is mostly limited to only part of the world (e.g. Australia in Digby et al. 1998 and Harris et al. 2002; USA in Engle et al. 2007) and they sometimes also originate from cluster analysis and thus do not provide easy-to-use criteria (e.g. Engle et al. 2007). Often, typologies are developed for a particular purpose and only describe single physical or geographical parameters, such as the hydrodynamics of a system (Carter and Woodroffe 1994), the degree of openness of an estuary (Bartley et al. 2001), vulnerability to sea level rise (Vafeidis et al. 2008) or one particular type of coast such as deltas (Davis and Fitzgerald 2004). Coastal segmentation approaches (Meybeck et al. 2006) provide geographical limits for budgeting of incoming riverine material fluxes at the global scale, but do not delineate the various types of coastal areas specifically. Finally, available maps of the global geographic distribution of coastal types typically leave some regions unclassified or include overlapping sections (Dolan et al. 1975). There is thus still a need for a global, comprehensive morphological coastal typology useable to distinguish types of coast that can be identified in terms of the filtering effect of incoming riverine material, i.e. as the fraction of the material effectively retained within the estuary through burial or removed through other chemical processes.

Here, we present a spatially explicit global typology, consisting of a 'ribbon' of cells distributed along the entire global coastline at a $0.5^{\circ}$ resolution that is based on hydrological, lithological and morphological criteria. The typology was developed in a GIS framework, making it easy to use and distribute. Additionally, more than 300 objects, i.e. individual bays (such as Chesapeake Bay), lagoons (such as Patos lagoon in Brazil), fjords or other systems, are described using higher-resolution data sets. Our operational typology at half degree resolution provides a direct link to well-established databases for continental river basins at the same scale such as the simulated topological network (STN-30) by Vörösmarty et al. (2000a, b). The typological approach allows the development of tools for inventory and comparison of systems. Hence, this typology can find applications that range from global mapping, regional and global budgeting of material fluxes to nutrient modelling. Furthermore, we provide an inter-type comparison of basic hydrodynamical properties and propose a revised number for the Woodwell et al. (1973) estimate of the global estuarine surface area.

\section{Methods}

\section{General Approach}

We define a set of four main estuarine filter types, plus three additional types for other types of coast. They are mapped according to the limits of the STN-30 river basins (Vörösmarty et al. 2000a, b), and each final terrestrial cell is labelled with a typology code for the type of receiving coastal water body: type I-small deltas, type II-tidal systems, type III — lagoons, type IV — fjords and fjärds plus large rivers (type V) as well as karst-dominated stretches of coast (type VI) and dry (arheic) areas (type VII).

The systems included in our analysis comprise all nearshore filter types, i.e. 'estuaries' in the widest sense (Schwartz 2005), representing the body of water bordered by rivers on the upstream boundary and the open waters of the continental shelf on the downstream boundary. This is consistent with boundaries found in the literature for individual systems. We are aware that different types of nearshore coastal water bodies can be divided into dozens of additional second-order or third-order types (e.g. Meybeck et al. 2004; Vafeidis et al. 2008). However, when mapping types at a global scale, there is a need for simplification and the introduction of groups of types 
where specialists would suggest important differences. We focus on the long-term filtering function for incoming riverine material. Material temporarily trapped at low tides or seasonally and released during subsequent high water stages or seasons is therefore not considered here. This implies that the types mapped here are stable over considerable time, at least of the order of tens of years. Furthermore, with our $0.5^{\circ}$ spatial resolution, we characterise the dominant coastal types over $\sim 50-\mathrm{km}$ coastal stretches. We do not aim at distinguishing local differences, such as variations in shores within a single delta.

\section{Conceptual Definition of Types}

Our typology only concerns exorheic river basins (i.e. draining into the oceans) and aims at describing the interface between continents and the open ocean. Hence, large inner parts of continents are not included in this study for the sole reason that they flow towards enclosed internal seas such as the Caspian Sea, Aral Sea or Lake Chad (i.e. they are endorheic). Our typology refers to coastal channels and waters, not the terrestrial environment, such as a delta surface. The physical characteristics of all seven types are shown in Fig. 1.

\section{Type I: Small Deltas}

A delta is a coastal landform created by sediment deposition at the mouth of a river, forming an alluvial landscape, and where the sediment supplied to the coastline is not removed by tides or waves (Schwartz 2005). Several forms of deltas are distinguished, e.g. river-dominated, wave-dominated or tidedominated deltas, not all leading to the classical deltaic form, coined after the Nile River delta by Herodotus (Schwartz 2005). However, many deltas worldwide have such high discharge and incoming material rates that limited filtering occurs in the internal delta channels (Meybeck et al. 2004). As such, most of the deltas mapped in this class are comparatively small, while many of the rivers possessing larger, wellknown deltas have been indicated as 'large rivers' (type V).

\section{Type II: Tidal Systems}

As opposed to river deltas that protrude onto the receiving shelves, tidal systems are here defined as a river stretch of water that is tidally influenced. This definition includes rias, i.e. drowned river valleys, and tidal embayments and classical funnel-shaped estuaries that are usually characterised by comparable residence times.

\section{Type III: Lagoons}

Coastal lagoons are comparatively shallow water bodies that are separated from the open ocean by a barrier, such as sandbanks, coral reefs or barrier islands (Schwartz 2005). Lagoons are generally less than $5 \mathrm{~m}$ deep, very elongated but narrow and are commonly orientated parallel to the coast, due to the influence of coastal currents dominating over incoming river fluxes (Meybeck et al. 2004). The definition extends to any enclosed shallow body of water situated between the river and the coast where tidal
Fig. 1 Estuarine filter types with their physical boundaries, including bedrock limit, the pertaining emerging part of the coast, and fine sediment deposit zones. For further details, see text

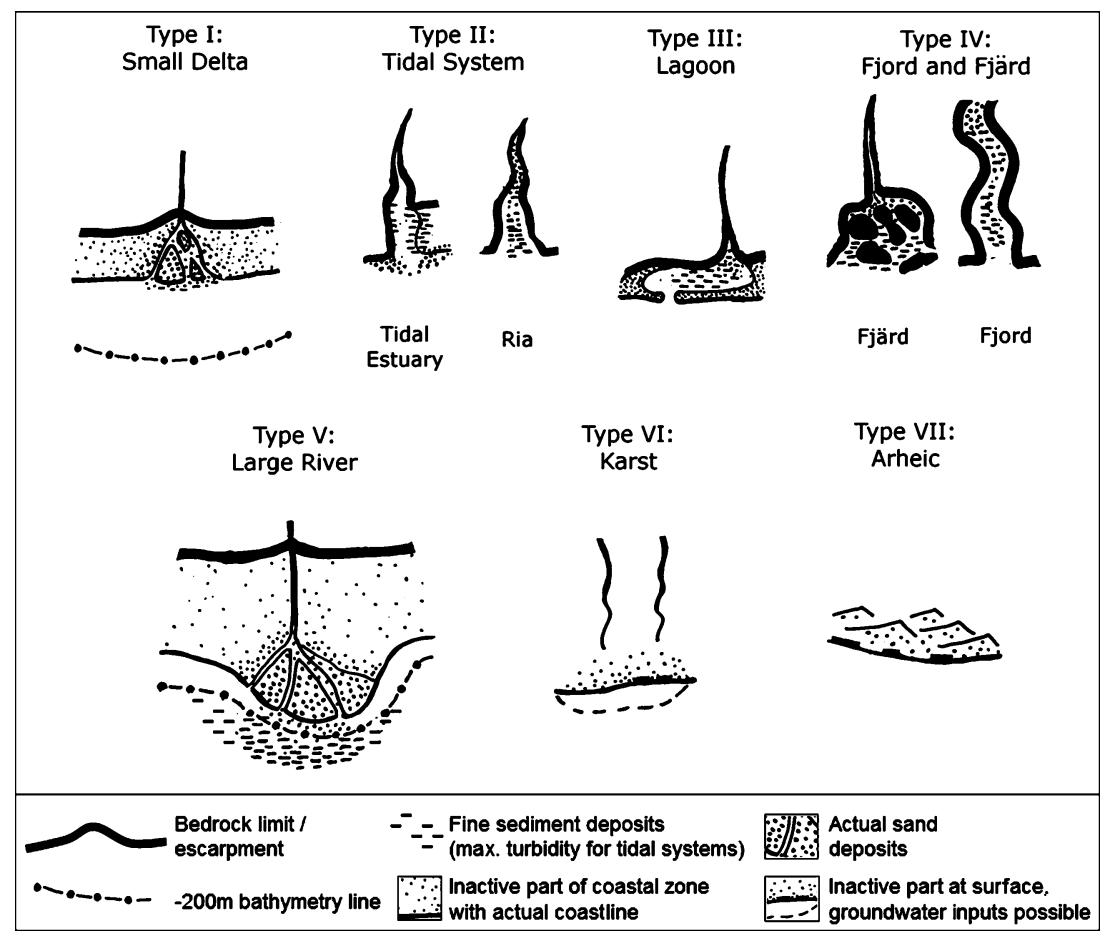


influence in general is minimal. They are characterised by relatively calm waters and long residence times (several months to several years). Smallest systems where lagoons form seasonally only are not taken into account here.

\section{Type IV: Fjords and Fjärds}

Fjords are classical U-shaped valleys created by glaciers that were drowned and are thus characterised by long, often narrow inlets with very steep topographies (Syvitski et al. 1987). Major fjords can be very deep, such as the Sognefjord in Norway that reaches depths of over 1,000 m (Sørnes and Aksnes 2006). Fjords generally are separated from the open sea by a sill or rise at their mouth, due to the presence of the former glacier's terminal moraine. Fjärds are wider and shallower and have more gentle, lateral slopes. They share the glacial origin and are characterised by many islands. A typical representative of this type of coast is the Swedish coast around Stockholm.

\section{Limited or Non-filter Types}

Type V: Large Rivers In this type, the major biogeochemical processing of incoming river fluxes, especially at high flow stages when the comparatively largest amounts of material are delivered, takes place in a plume on the continental margin (type V-large rivers, or 'RiOMars', i.e. river-dominated ocean margins, Dagg et al. 2004; McKee et al. 2004). Meybeck et al. (2004) have remarked that deltas generated by high runoff and high erosion rivers are also very limited filters, i.e. the filtering capacity is mostly effective during low flows and is very reduced at high flows. Some of these large systems may be influenced by tides: Ebb and flood tides tend to flow through different channels, and tide-dominated deltas are characterised by a braiding network of streams and many islands. We therefore include a subtype (type $V_{b}$ ) for tidal large rivers.

Type VI: Karst-Dominated Coast Karst describes a system of landforms that are dominated by dissolution of carbonate rock (Ford and Williams 1989). This leads to distinct landscapes, such as observed along the coasts of the Eastern Adriatic, Northern Borneo or parts of Vietnam (Ha-Long Bay; Herak and Stringfield 1972). Submarine groundwater discharge is important in these areas (Slomp and Van Cappellen 2004; Fleury et al. 2007). While multiple submarine 'point' sources of continental waters thus occur, surface fluxes are generally negligible.

Type VII: Arheic Coast In arid regions, such as deserts, runoff is so low that significant stretches of coast are characterised by a near-total absence of water inputs (arheism, conventionally set to runoff $<3 \mathrm{~mm}$ year $^{-1}$; Vörösmarty et al. 2000a, b; Fekete et al. 2002) from the continent to the ocean.

\section{Determination of Types of Estuarine Coastal Filters}

The development of the typology consisted of several successive steps, following a decision tree (Fig. 2) using an iterative process that included multiple verifications, and decisions on the identification and clustering of various coastal types.

\section{Step 1: Exorheic vs. Endorheic Parts of the Continents}

Endorheic river basins flow towards internal seas and lakes. Hence, the material carried never reaches the ocean. The digitized global potential river network (Vörösmarty et al. 2000a, b) was used to distinguish between systems draining to the external parts of the continents (exorheism) vs. internal basins (endorheism).

\section{Step 2: Limited or Absent Filter: Rheism-Arheism, Karst}

The second step involved establishing whether a river basin is intercepted by an estuarine filter before reaching the coastal ocean. Such a filter can be absent due to arheism, or submarine groundwater discharge. Arheic systems were differentiated from rheic systems when average runoff over the whole watershed is less than $3 \mathrm{~mm}$ year ${ }^{-1}$ (Vörösmarty et al. 2000a, b; Fekete et al. 2002). Carbonate rock dominance on the last terrestrial cell of the upstream river basin (Dürr et al. 2005) was used to indicate karst occurrence (type VI). Larger systems mostly develop other dominant types of coast, and dominant coastal karst occurrence is thus mostly limited to catchments with very few upstream cells.

\section{Step 3: Estuarine Filters-External Filters}

Large rivers produce estuarine plumes that extend far beyond the defined limits of our estuarine filters and they are thus considered external filters (Meybeck and Dürr 2009). Sediments and other dissolved or particulate material are processed way beyond the nearshore area, and deposition can occur outside the limits of the continental plateau as defined by the $200-\mathrm{m}$ bathymetry line (Walsh 1988; Walsh and Nittrouer 2009). Based on McKee et al. (2004) and Dagg et al. (2004), we assume that the Rhône River (with a discharge of $52 \mathrm{~km}^{3}$ year $^{-1}$ ) is the smallest large river. The geographic distribution of large river deltas was assessed using available literature (Davis and Fitzgerald 2004; Ericson et al. 2006). Protruding deltas 


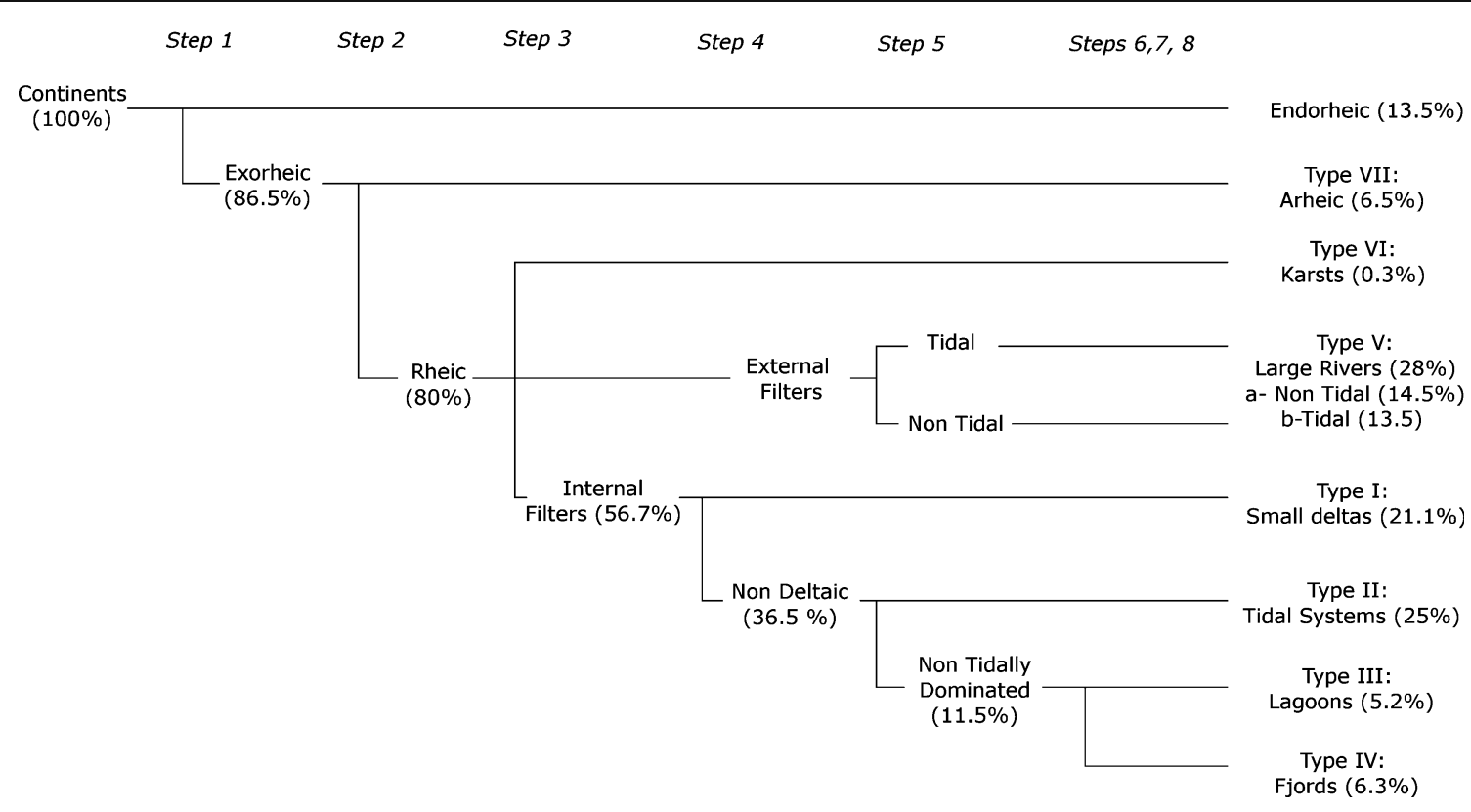

Fig. 2 Schematic of the hierarchical steps for type determination plus continental surface area distribution (in \%) of river basin catchments connected to the different types

were identified one by one using the form of the coastal morphology and the shape around the 200-m bathymetry line from the Smith and Sandwell (1997) dataset. Case-bycase verification revealed that most of the major deltas were associated to large rivers (type V). In some cases, large river systems were connected to large estuarine systems and were assigned to another type. Prominent examples are the $\mathrm{Ob}, \mathrm{St}$. Lawrence and the Parana and Uruguay (Rio de la Plata) rivers.

\section{Step 4: Remaining Smaller Deltas}

Small deltas (type I) were identified as remaining smaller deltas, mostly with surface areas (total delta area) $<1,000 \mathrm{~km}^{2}$. Additionally, small basins without distinct features, as well as rocky coasts and other miscellaneous types that could not be attributed to one of the other major coastal types, were clustered here.

\section{Step 5: Tidal Systems}

Tidally dominated systems were identified by combining coastline maps showing coastal embayments with global tide amplitude maps (Hayes 1979; Stewart 2000). All macrotidal systems (tidal amplitude $>2 \mathrm{~m}$ ) were included. Furthermore, some selected systems with tidal amplitude $>1 \mathrm{~m}$ were also chosen, based on morphological similarities with classical macrotidal estuaries. Additionally, rias were identified using the 'submerging' type on the map of Kelletat (1995). Systems such as the Delaware, Chesapeake Bay and San Francisco Bay are included here.
In some of the 'large river' systems (type V), tides can be important, when they propagate into the estuary. We have identified these systems as macrotidal (type $V_{b}$ ), using the information on tidal amplitude, combined with more detailed information for individual systems, such as the Amazon and Tocantins (Gallo and Vinzon 2005) and several Indian rivers (Harrison et al. 1997; Selvam 2003).

\section{Step 6: Lagoons}

River basins passing through coastal lagoons on their way to the sea were identified, based on coastal morphology (Kelletat 1995). We used a combination of the coastline shape with information derived from atlases (New York Times 1992) or imagery sources such as Google Earth (Google 2009). Lagoons unconnected to rivers were not included.

\section{Step 7: Fjords and Fjärds}

In our typology, fjords and fjärds were identified by systems characterised by combined (a) hard rock lithology and (b) maximum Quaternary glacier coverage extent, both derived from Dürr et al. (2005) and (c) coastline shape (New York Times 1992) and bathymetry (Smith and Sandwell 1997).

\section{Step 8: Overlapping Types}

In some cases, for single cells containing different types, a choice of a dominant type had to be made or several cells 
were grouped to a main type. The final type assignment was based on the net filter function of different types of coastal zones. Mostly, the order of priority for the attribution of the different types was established as follows (from highest to lowest): large rivers, lagoon, arheic, karst, fjord, tidal systems (estuary and ria), identifiable deltas, fjärd, miscellaneous, mostly remaining stretches of coast (mainly assigned as small deltas).

The four types of estuarine filters that are distinguished here are ranked in an increasing order of fresh water residence time, also called flushing time, calculated by dividing the volume of a system by its incoming water flow (Sheldon and Alber 2006). Table 1 summarizes how the morphological subtypes were derived from various sources.

\section{Individual Object Description}

A set of 302 of the most important individual estuarine systems distributed worldwide were manually delimited on a higher-resolution GIS using the 'GTOPO30' coast limit (USGS-EDC 1996), at a 0.5 -min resolution (about $1 \mathrm{~km}$ ). Figure 3 presents an example stretch of coast showing several of these systems along the North East Atlantic coast of the USA. The systems widely vary in size and morphological structure. The area of each system was established by connecting the outside limit points at the outlet of the systems. Note that the surface area defined here represents the water surface and does not include internal islands, salt marshes and other emerging features. This distinction is particularly important for deltas, since the delta surfaces available in the literature (Ericson et al. 2006) usually refer to the whole deltaic domain including the emerging, terrestrial, part. Each system was then assigned to an incoming river basin via its STN-30 v.6 basin number (Vörösmarty et al. 2000a, b). For each coastal object, we then calculated the water discharge (based on Fekete et al. 2002), sediment fluxes (based on Beusen et al. 2005) and associated catchment basin population (data from Vörösmarty et al. 2000c). In several cases, such as the Chesapeake Bay, the Ob/Pur-Taz basins or major lagoons (Patos, Laguna Madre), several STN-30 basins connect to the same coastal object (e.g. bay or lagoon), and the ensemble of the connected systems was considered when calculating the incoming fluxes and basin pressures (see the case of the Chesapeake Bay on Fig. 3).

In order to determine the volume of each of the individually identified systems, first a GIS standard algorithm was used to transform the geographical polygon shapes from the GTOPO30 coastline into raster grids. Then, a depth was assigned to each grid cell at a resolution of $1 \mathrm{~min}$, corresponding to the highest resolution of globally available consistent bathymetry data sets, in order to calculate the volumes by summarizing per object the multiplication of the depth of each grid cell with its surface area. The global bathymetric dataset used for this purpose was Smith and Sandwell (1997). Several other global bathymetry datasets were tested (ETOPO2 dataset (U.S. Department of Commerce, National Oceanic and Atmospheric Administration, National Geophysical Data Center 2006) and the GEBCO database (GEBCO 2007)), but the Smith and Sandwell (1997) data gave the best overall picture when compared to high-resolution data available for individual systems in the literature.

For validation purposes, surface areas and volumes of 18 systems were collected from the literature (Table 2). Despite the emphasis on tidal temperate estuaries and lagoons in many coastal studies, our collection was as representative as possible and also included fjords and several small deltas. A good correlation was observed for the surface areas between the GIS calculation and the literature values (Fig. 4a). The robustness of the method decreases for estuaries smaller than $300 \mathrm{~km}^{2}$ (about the size of the Scheldt estuary or Apalachee Bay). In some cases, the complex boundary of a system makes a proper definition of the deltaic shape difficult. For example, this is the case for the Pearl River, which is described as having a surface area of $1,970 \mathrm{~km}^{2}$ by Wong and Cheung (2000), while we estimate an area of $2,753 \mathrm{~km}^{2}$.

The calculated volumes for the validation set correlate well with the observed values (Fig. 4b). In contrast to the trend observed for the surface area, the largest systems do not necessarily show the best fit. This is partly due to the deep fjords which are poorly described in bathymetric datasets (Smith and Sandwell 1997). Overall, systems larger than $4 \mathrm{~km}^{3}$ do not differ by more than $50 \%$, which is the order of magnitude of the tidal prism in many macrotidal systems (Monbet 1992).

\section{Results and Discussion}

\section{Spatial Distribution and Heterogeneity of Types}

The worldwide distribution of the various types of estuarine filters reveals a large heterogeneity between continents and between oceanic basins, but also very clear geographical patterns (Fig. 5). Major world river basins and their coastal type are described in Table 3. The observed distribution stems from a complex interplay of different factors influencing the coastal morphology, from genetic origins such as geological or glacial history to differences between the energy provided by rivers or tides, to differences between types due to a varying influx of water and sediments associated with climate, vegetation, relief, soils and other characteristics of the upstream basin. 


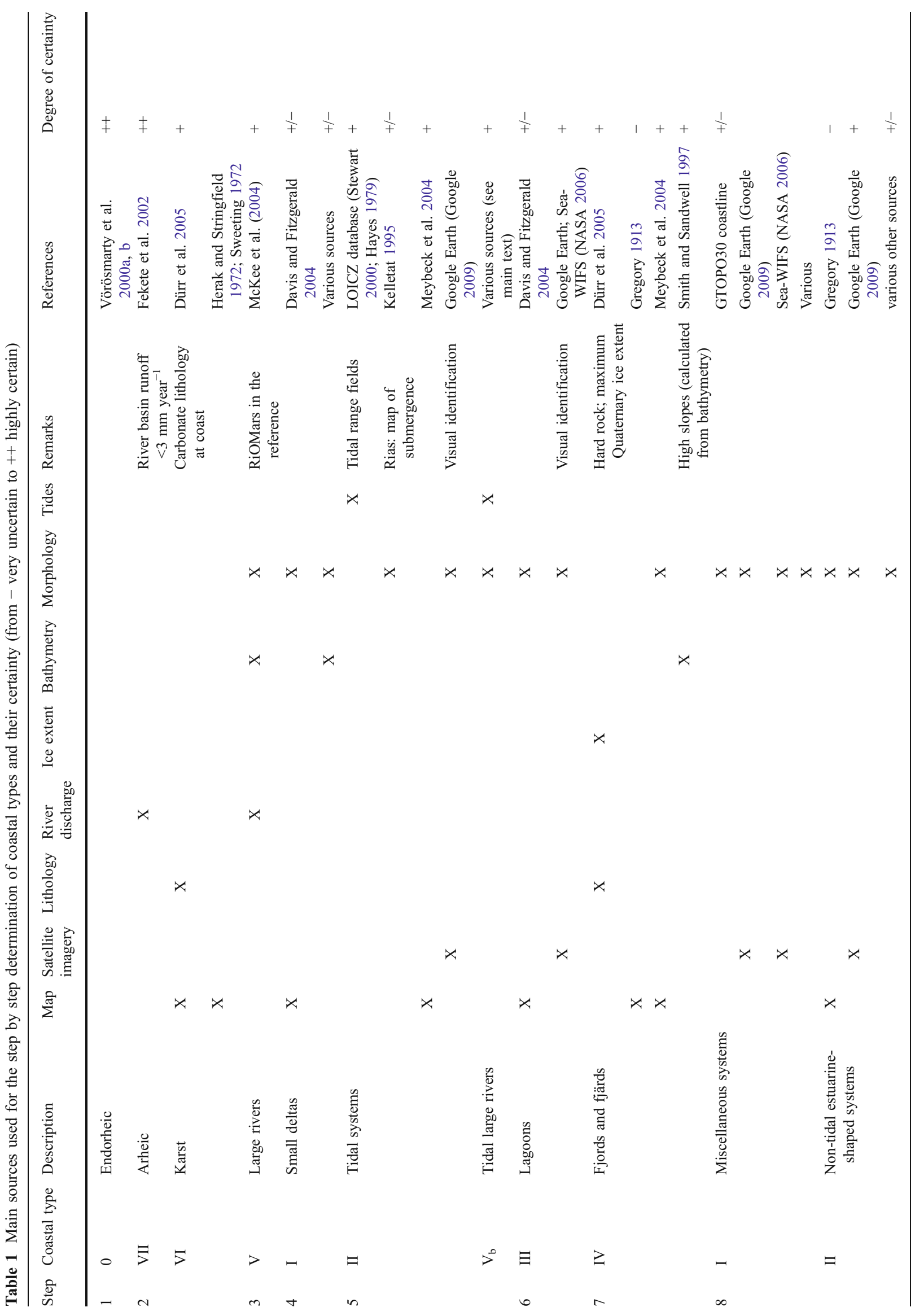


Fig. 3 Examples of estuarine objects along the Eastern coast of the USA. Physical boundaries of objects are detailed; connected river basins at STN30 resolution $\left(0.5^{\circ}\right)$ are shown, together with the colour of the corresponding coastal type. Names of major river basins are highlighted and STN-30 v.6 basin numbers of all river systems connected to a single coastal entity/object are given. Estuarine surface area is also shown

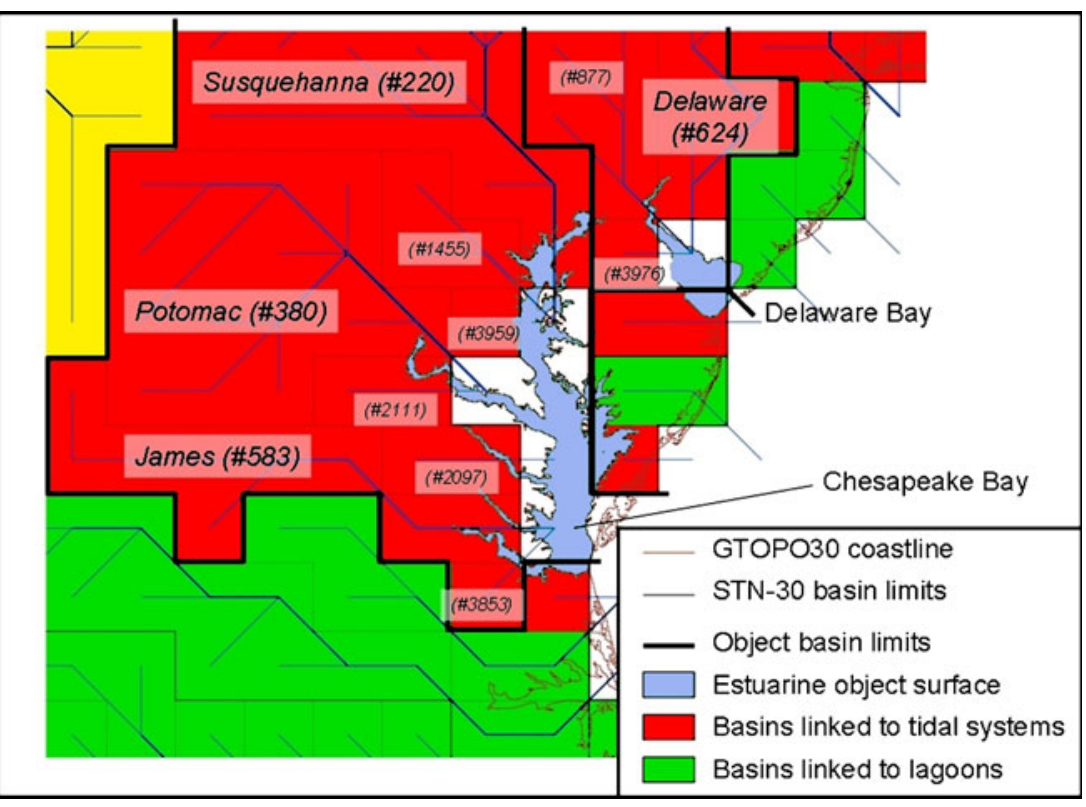

The majority of endorheic river basins are located in Eastern Europe and Central Asia (62\% of the endorheic continental area). The surfaces of the remaining continental surface landmass are widely dominated by exorheic river basins. In South and North America as well as Africa, the fraction of the watershed surface occupied by large rivers is the largest. These systems contribute to $41.6 \%$ of the continental water discharge, $25.7 \%$ of sediment load (mostly from tidal large rivers) and $33.6 \%$ of the exorheic land area, but they provide runoff to less than $1 \%$ of the global coastline (Table 4). This also leads to a biased distribution of the population. While $26.4 \%$ of the total population live in these areas, only $1.9 \%$ live in coastal areas connected to large rivers.

Table 2 Calculated and observed (when available) estuarine surface areas $\left(A_{\mathrm{e}}\right)$ and estuarine volumes for selected near shore coastal systems that were manually delimited

\begin{tabular}{|c|c|c|c|c|c|c|}
\hline \multicolumn{2}{|l|}{ System } & \multicolumn{2}{|l|}{$A_{\mathrm{e}}\left(\mathrm{km}^{2}\right)$} & \multicolumn{2}{|c|}{ Volume $\left(\mathrm{km}^{3}\right)$} & \multirow[t]{2}{*}{ Reference } \\
\hline Name & Type & Calculated & Observed & Calculated & Observed & \\
\hline Bug & II & 61 & 50 & n.a. & n.a. & Dziganshin and Yurkova (2001) \\
\hline Chesapeake Bay & II & 10,073 & 11,542 & 82.7 & 69.3 & Nixon et al. (1996) \\
\hline Delaware Bay & II & 1,980 & 1,989 & 15.4 & 19.3 & Nixon et al. (1996) \\
\hline Dnieper & II & 741 & 750 & 8.3 & 3.0 & Dziganshin and Yurkova (2001) \\
\hline Gironde & II & 604 & 635 & n.a. & n.a. & Audry et al. (2007) \\
\hline $\mathrm{Ob}$ & II & 34,790 & 40,800 & 813.5 & 612.0 & Ivanov (1991) \\
\hline Pearl River & II & 2,753 & 1,970 & 19.6 & 11.6 & Wong and Cheung (2000) \\
\hline Scheldt & II & 383 & 277 & 4.1 & 3.1 & Nixon et al. (1996) \\
\hline Apalachicola Bay & III & 813 & 260 & n.a. & n.a. & Mortazavi et al. (2000) \\
\hline Curonian Lagoon & III & 1,602 & 1,584 & 7.8 & 6.2 & Stankevicius (1995) \\
\hline Don (Azov Sea) & III & 37,077 & 40,000 & 347.2 & 320.0 & Tolmazin (1985) \\
\hline Maracaibo Lake & III & 12,695 & 13,210 & 263.1 & 280.0 & Laval et al. (2005) \\
\hline Oder Lagoon & III & 844 & 1,000 & 9.2 & 3.5 & Grelowski et al. (2000) \\
\hline Patos Lagoon & III & 9,851 & 10,000 & n.a. & n.a. & Castelao and Moller (2006) \\
\hline Venice Lagoon & III & 388 & 500 & 4.6 & 1.0 & Solidoro et al. (2005) \\
\hline Vistula Lagoon & III & 740 & 838 & 4.3 & 2.3 & Chubarenko and Margoński (2008) \\
\hline Aysen Fjord & IV & 263 & 350 & n.a. & n.a. & Marín et al. (2008) \\
\hline Sognefjord & IV & 898 & 950 & 310.8 & 530.0 & Sørnes and Aksnes (2006) \\
\hline
\end{tabular}

N.a. not available 

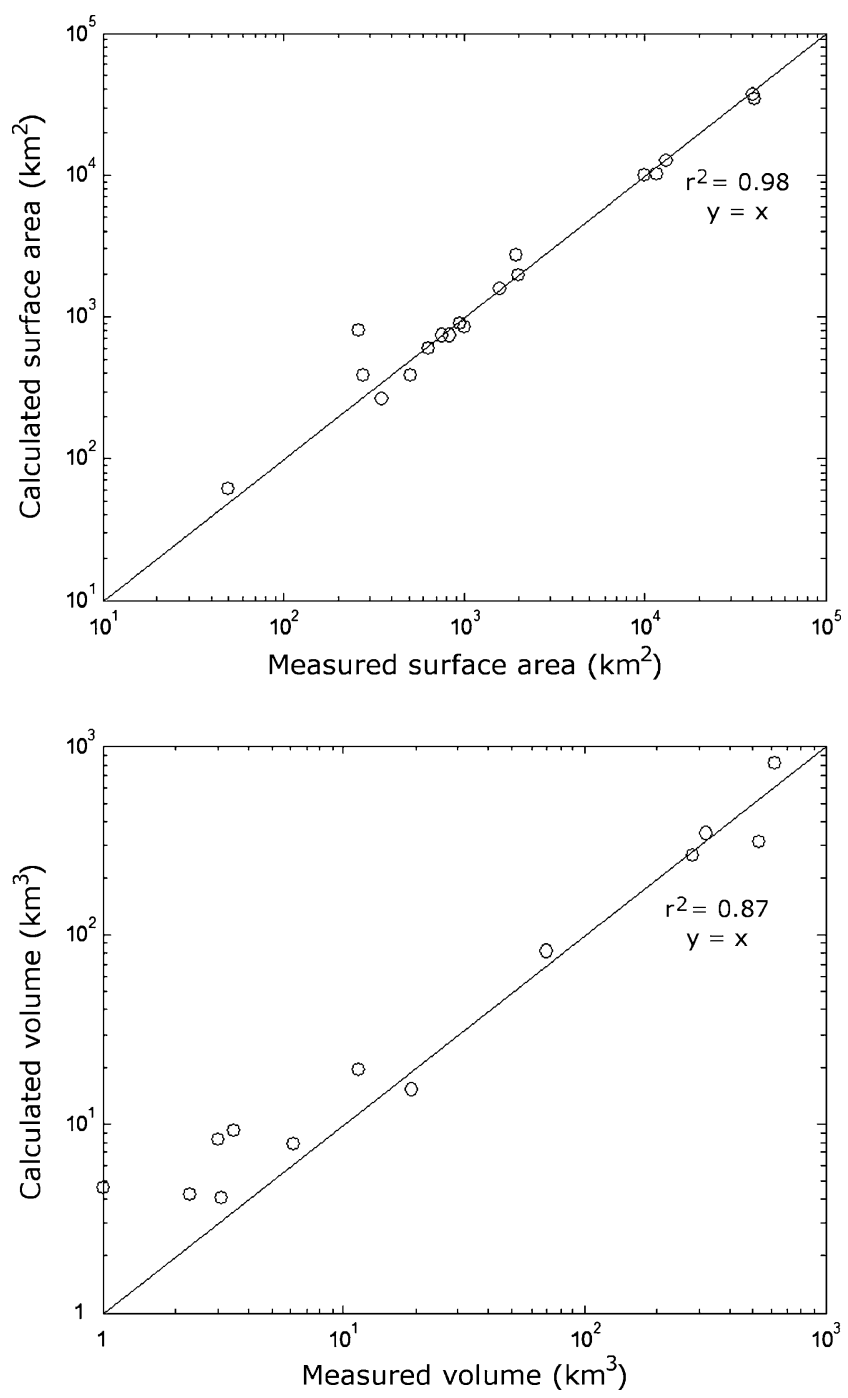

Fig. 4 Comparison of measured and calculated surface areas and volumes for 18 systems (see Table 3 ) for validation. The regression equations $(y=x)$ are forced

Other coasts without estuarine filters (types VI and VII) are mainly located in tropical and subtropical regions where they represent $22 \%$ of the coastline between $30^{\circ} \mathrm{N}$ and $30^{\circ}$ $\mathrm{S}$ and $11 \%$ of the global coastline. Coastal karst is primarily found in (sub-)tropical and equatorial areas such as Florida, the Eastern Adriatic coast or parts of Northern Borneo. They only represent $2.4 \%$ of the world's coastline and account for only $0.8 \%$ of its river discharge. The remainder of the non-filter coast consists of arid regions such as the Arabian Peninsula, northern Africa and along subtropical borders of the West Pacific. Australia alone accounts for $7 \%$ of the arheic coastline.

Nearly $57 \%$ of the world's exorheic river water discharge and $71 \%$ of the sediment discharge to the oceans pass through estuarine filters (Table 4). In terms of coastline distribution, estuarine filters account for approximately $88 \%$ of the worldwide exorheic coastline. Types I and III are heterogeneously distributed around the globe. Long stretches of the Siberian coast consist of large rias (type II). Lagoons are particularly well represented between the equator and $40^{\circ} \mathrm{N}$. This is largely due to the, sometimes nested, lagoons of the Gulf of Mexico, Florida and the South East coast of the USA. In Europe, the northern part of the Black Sea including the Azov Sea is treated as a mega lagoon. The remainder of the lagoons is distributed more or less equally along all continents and latitudes. Tidal systems and small deltas (types II and I) occur across all climate zones. Their distribution varies significantly from one continent to the other. Western Europe, northern Asia and South East China can be qualified as dominated by tidal-type coasts, while sub-equatorial Africa, India, Indonesia, Northeast China and Japan are dominated by small deltas. North America as well as eastern South America exhibit significant stretches of coastline from each type and Central America appears dominated by lagoons (type III) on its Atlantic side and by small deltas (type I) on its Pacific side. Fjords (type IV), however, are essentially concentrated in Scandinavia, Canada, Alaska and southern Chile, plus a few coasts of New Zealand, due to their origin in formerly glaciated areas. Fjords account for $75 \%$ of the coastline north of $70^{\circ} \mathrm{N}$.

Differences also show up when mapping river basins connected to a particular type of coast and coastal cells alone (Fig. 5a, b, respectively). This is indeed somewhat a consequence of our type definition and is particularly evident in regions such as East Asia where most of the major watersheds are connected to tidal systems (type II) while most of the coastline actually consists of small deltas. This discrepancy between watershed area and coastline length is also observed for lagoons that typically have comparatively small river basins, as for the Brazilian coast. Although fjords are completely absent in Africa and almost non-existent in Asia and Oceania, the other types are represented on all continents. Consequently, there is a real difference between the spatial distribution of estuarine filters along the coastline (Fig. 5b) and the watershed area connected to the filters (Fig. 5a). While the first provides a realistic representation of estuarine filters, the latter provides an indicator of relative river contribution. As an example, $61 \%$ of the water flowing into the Atlantic does not encounter an estuarine filter, due to the large contributions of the Amazon $\left(6,548 \mathrm{~km}^{3}\right.$ year $\left.{ }^{-1}\right)$, Mississippi $\left(639 \mathrm{~km}^{3}\right.$ year $\left.^{-1}\right)$ and Congo/Zaire $\left(1,330 \mathrm{~km}^{3}\right.$ year $\left.^{-1}\right)$. The contribution of the Orinoco $\left(1,106 \mathrm{~km}^{3}\right.$ year $\left.{ }^{-1}\right)$, in contrast, is filtered by an estuary.

\section{Clusters of Types and Their Origins}

To highlight some of the key characteristics of each coastal type with respect to runoff and sediment transport charac- 

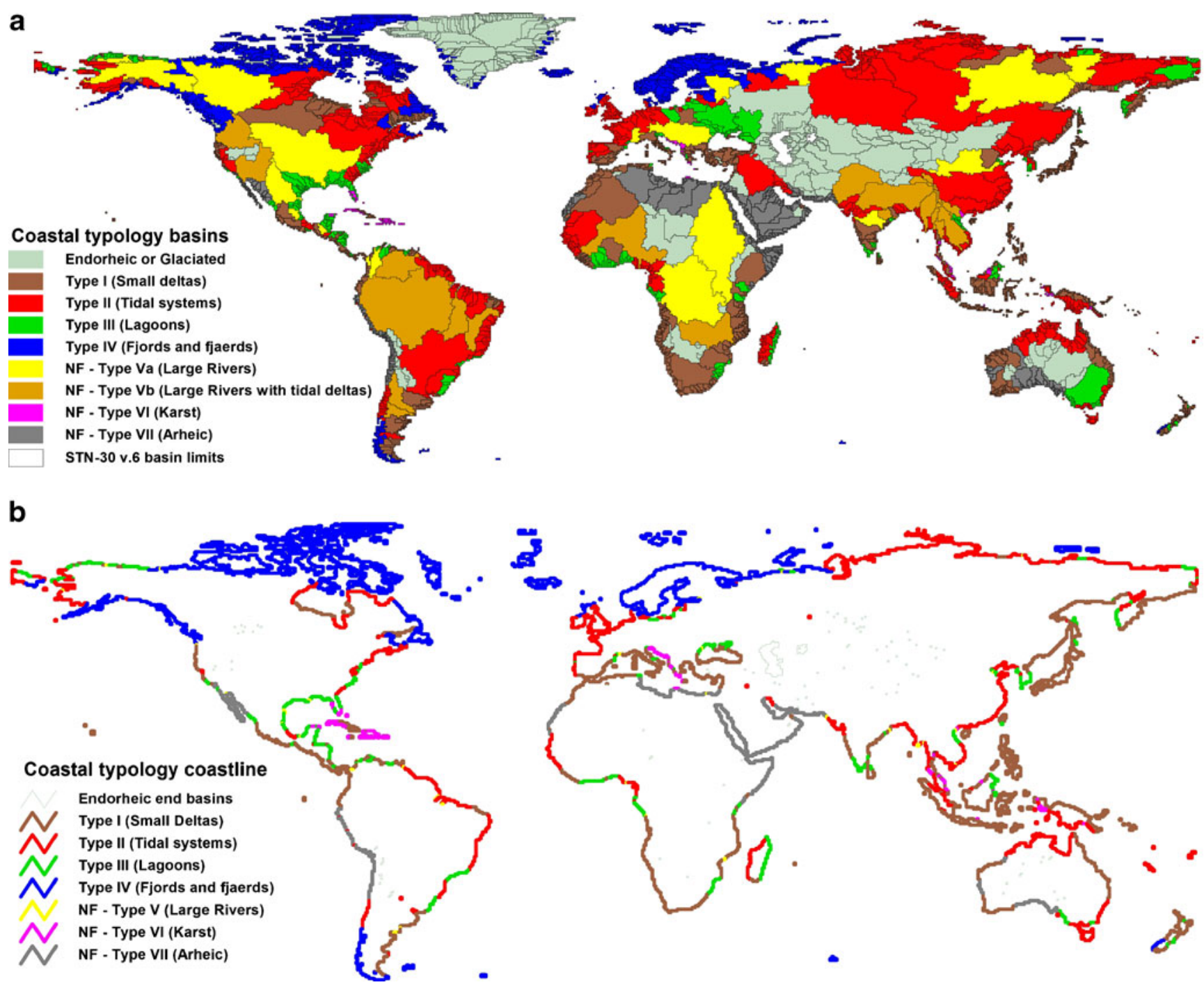

Fig. 5 Spatial distribution of the internal filters according to their type. On the top panel (a), the whole watersheds are coloured while only the coastline is designated on the bottom panel (b)

teristics, a cluster analysis was carried out for a subset of the 302 individual objects. We used the estuarine surface area $\left(A_{\mathrm{e}}\right)$, estuarine volume $\left(V_{\mathrm{e}}\right)$, watershed surface area $\left(A_{\mathrm{b}}\right)$, annual river water discharge $(Q)$ and sediment load $(S$; Figs. 6 and 7). The latter three data sets were obtained from global statistical model outputs within the STN-30 and GlobalNEWS framework (Vörösmarty et al. 2000a, b; Fekete et al. 2002; Beusen et al. 2005; Seitzinger et al. 2005). In order to comply with guidelines regarding the accuracy of these values (Seitzinger et al. 2005), the smallest watersheds $(<8$ continental cells) were excluded from the analysis. Due to the very limited number of objects that can actually be spatially delimited for small deltas ( $<5$ items), we included seven large deltas worldwide where the GTOPO30 detailed coastline allowed an identification of the estuarine water surface area. While these systems are different from small deltas in terms of filtering (e.g. external plumes vs. internal filtering), most of the 'large rivers' are actually deltas and can be studied together from a geomorphological point of view for the cluster analysis. Included are the Amazon, Nile, Mississippi, Lena, Mackenzie, Indus and Yukon deltas, attributed as 'large rivers' (type V). This procedure allowed us to obtain a somewhat larger set of data for deltas.

We calculated various parameters (Fig. 6a-d) for each type: (a) the $W_{\mathrm{e}}$ index which is defined as the annual river water discharge divided by the estuarine surface area $(Q /$ $A_{e}$ ), thus representing the average amount of water received per unit area collected by the estuarine object; (b) the $S_{\text {e }}$ index, which is calculated in the same way using the annual sediment wash load $\left(S / A_{\mathrm{e}}\right)$; (c) the flushing time, or river water residence time, for each system $\left(V_{\mathrm{e}} / Q\right)$ and (d) the ratio of basin area to estuarine surface area $\left(A_{\mathrm{b}} / A_{\mathrm{e}}\right)$. Despite a wide heterogeneity, the $W_{\mathrm{e}}$ index tends to be high for tidal 
Table 3 List of the world's 100 largest river basins and the type of filter per continent

\begin{tabular}{|c|c|c|c|c|c|c|}
\hline & Endorheic & Type I & Type II & Type III & Type IV & Type V \\
\hline North America & & Nelson & $\begin{array}{l}\text { Saint Lawrence } \\
\text { San Francisco Bay } \\
\text { Baker }\end{array}$ & & $\begin{array}{l}\text { Frasier } \\
\text { Churchill } \\
\text { Colombia }\end{array}$ & $\begin{array}{l}\text { Mississippi } \\
\text { Colorado } \\
\text { RioGrande } \\
\text { Mackenzie } \\
\text { Yukon }\end{array}$ \\
\hline South America & & Salado & $\begin{array}{l}\text { Parana } \\
\text { Chubut } \\
\text { Uruguay } \\
\text { Parnaiba }\end{array}$ & & & $\begin{array}{l}\text { Amazon } \\
\text { Orinoco } \\
\text { Tocantins } \\
\text { Magdalena } \\
\text { Colorado } \\
\text { Negro Arg. }\end{array}$ \\
\hline Europe & Volga & & Dvina & $\begin{array}{l}\text { Dnepr } \\
\text { Don }\end{array}$ & & $\begin{array}{l}\text { Danube } \\
\text { Neva } \\
\text { Pechora }\end{array}$ \\
\hline Africa & $\begin{array}{l}\text { Lake Chad, Tamanrasett, } \\
\text { Bodele Depression, Okavango } \\
\text { Lake Rudolf }\end{array}$ & $\begin{array}{l}\text { Volta } \\
\text { Orange } \\
\text { Jubba }\end{array}$ & $\begin{array}{l}\text { Ogooue } \\
\text { Senegal }\end{array}$ & Kouliou & & $\begin{array}{l}\text { Zaire } \\
\text { Nile } \\
\text { Niger } \\
\text { Zambezi }\end{array}$ \\
\hline North Asia & & $\begin{array}{l}\text { Limpopo } \\
\text { Yana } \\
\text { Olenek }\end{array}$ & $\begin{array}{l}\text { Yenisei } \\
\text { Ob } \\
\text { Amur } \\
\text { Khatanga } \\
\text { Kolyma }\end{array}$ & Anadyr & & $\begin{array}{l}\text { Lena } \\
\text { Indigirka }\end{array}$ \\
\hline South East Asia & $\begin{array}{l}\text { Amu-Darya, Tarim, Kerulen, } \\
\text { Syr-Darya, Farah, Garagum, } \\
\text { Ruo Dong, Shur, Dzungarian, } \\
\text { Jaji, Ural, Lake Balkhas, Kure, } \\
\text { Ili, Qarqan, Za'gya, Bogea }\end{array}$ & $\begin{array}{l}\text { Krishna, } \\
\text { Hai Ho }\end{array}$ & $\begin{array}{l}\text { Chang Jiang } \\
\text { Zhujiang } \\
\text { Shatt el Arab } \\
\text { Liao } \\
\text { Huai }\end{array}$ & & & $\begin{array}{l}\text { Ganges } \\
\text { Mekong } \\
\text { Irrawaddy } \\
\text { Salween } \\
\text { Godavari } \\
\text { Huang He } \\
\text { Indus }\end{array}$ \\
\hline Australia/Oceania & $\begin{array}{l}\text { Great Artesian Basin, Lake Eyre } \\
\text { Mac Key } \\
\text { Lake Frome }\end{array}$ & Taymyr & & Murray & & \\
\hline
\end{tabular}

systems and low for lagoons. Both types comprise small and large watersheds, unlike fjords which are mainly fed by river basins of modest size $\left(<10^{5} \mathrm{~km}^{2}\right)$ and consequently rather limited incoming discharge. For the $S_{\mathrm{e}}$ index, the heterogeneity within types is larger than for the $W_{\mathrm{e}}$ index but, in general, tidal systems exhibit a higher incoming sediment charge per estuarine area while few lagoons and fjords reach $10^{3} \mathrm{t}$ sediment square kilometres per year. Overall, it appears that, in spite of their usually large surfaces, fjords collect relatively modest discharge and sediment per surface area. Lagoons and tidal systems can have a wide range of river basin sizes, but the latter are characterised by higher $W_{\mathrm{e}}$ and $S_{\mathrm{e}}$.

The relation between incoming riverine water fluxes and estuarine area and volume is reflected in varying flushing times per coastal type. Overall, tidal systems have shorter residence times than lagoons while fjords possess the longest residence times. Deltas have comparatively low flushing times (Fig. 6c), due to the interplay of high incoming water fluxes from large river basin areas (Figs. 6d and 7a) with often comparatively low estuarine volumes. A comparison between flushing times and river basin area (Fig. 7b) exhibits a trend for shorter water residences time with increasing watershed area. Fjords (type IV) stand out clearly with high flushing times and modest basin areas, whereas lagoons have slightly elevated flushing times with restricted variability, despite large variation in basin areas (Fig. 6c and 7b). The median flushing times are 0.08, 0.27, 0.78 and 10.2 years for types I, II, III and IV, respectively. 


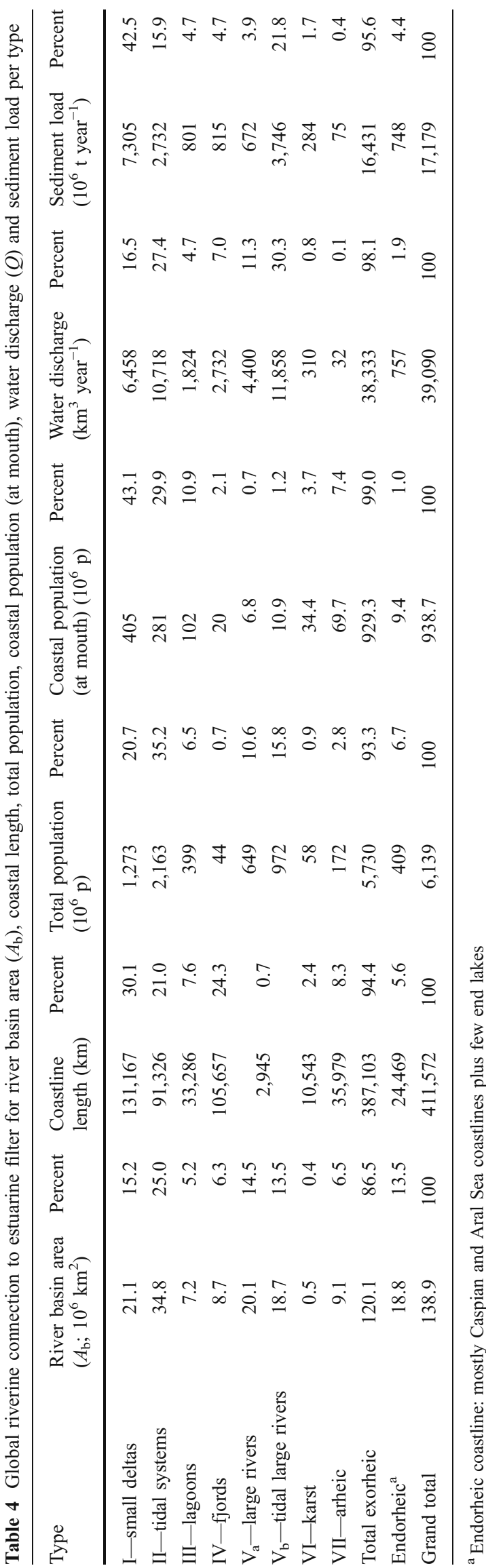

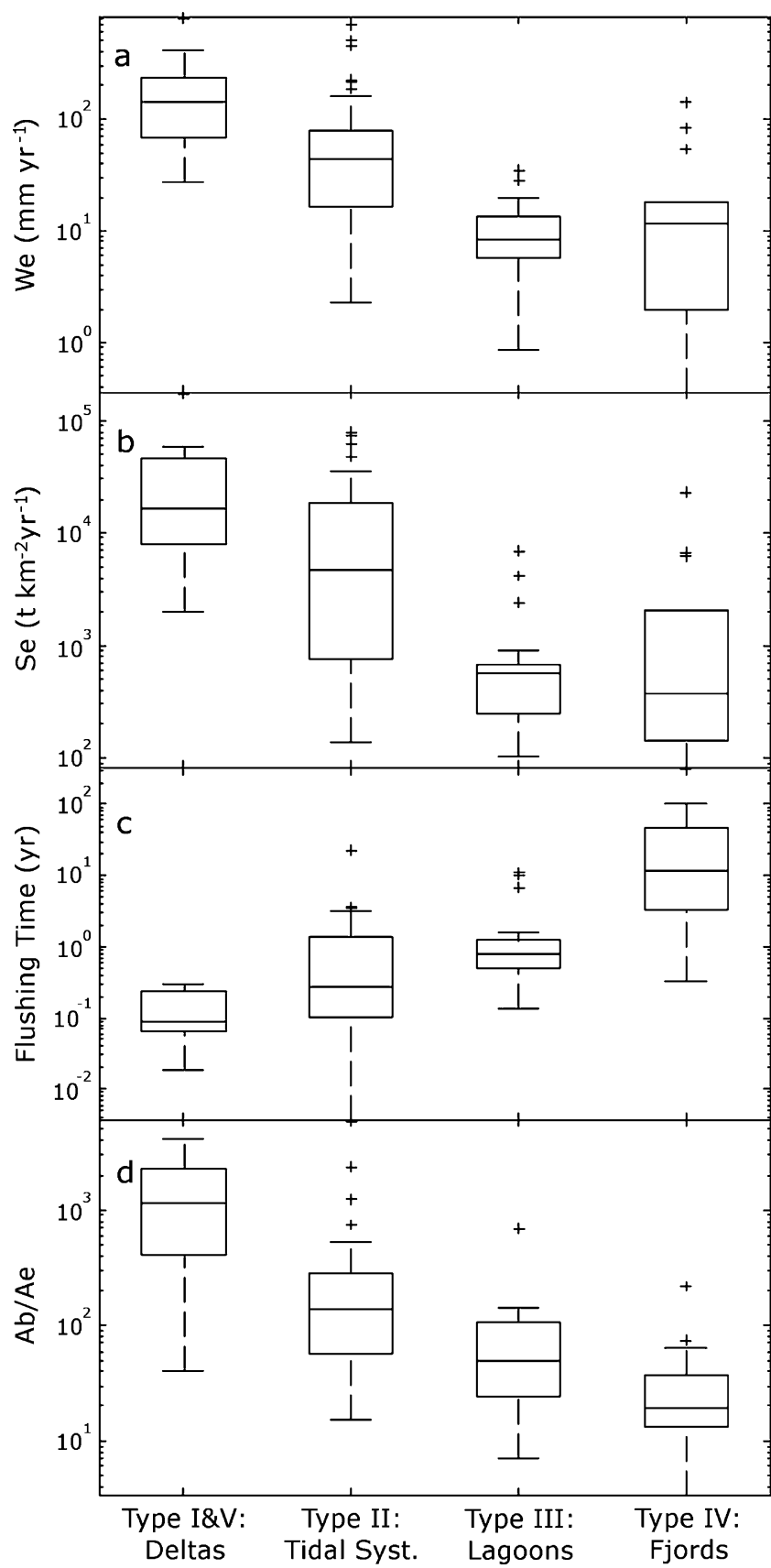

Fig. 6 Boxplot of the distribution of the $W_{\mathrm{e}}$, which is defined as the annual rivers discharge divided by the estuarine surface area $\left(Q / A_{\mathrm{e}} ; \mathbf{a}\right)$, $S_{\mathrm{e}}$, which is the ratio of the annual sediment load and estuarine surface area $\left(S / A_{\mathrm{e}} ; \mathbf{b}\right)$, flushing time $(\mathbf{c})$, and ratio of the estuarine surface area and river basin area $\left(A_{\mathrm{e}} / A_{\mathrm{b}} ; \mathbf{d}\right)$ per filter type

The direct comparison of sediment loads against water discharge displays a linear relationship, well-known from the literature on river sediment load (Walling and Fang 2003), and here we chose to rather report these values against river basin area, i.e. sediment yield vs. river runoff (Fig. 7c). The data, however, are very scattered. As to be expected, lagoons have rather low sediment yields and river runoff, with few exceptions, and deltas tend to have higher incoming yields. 

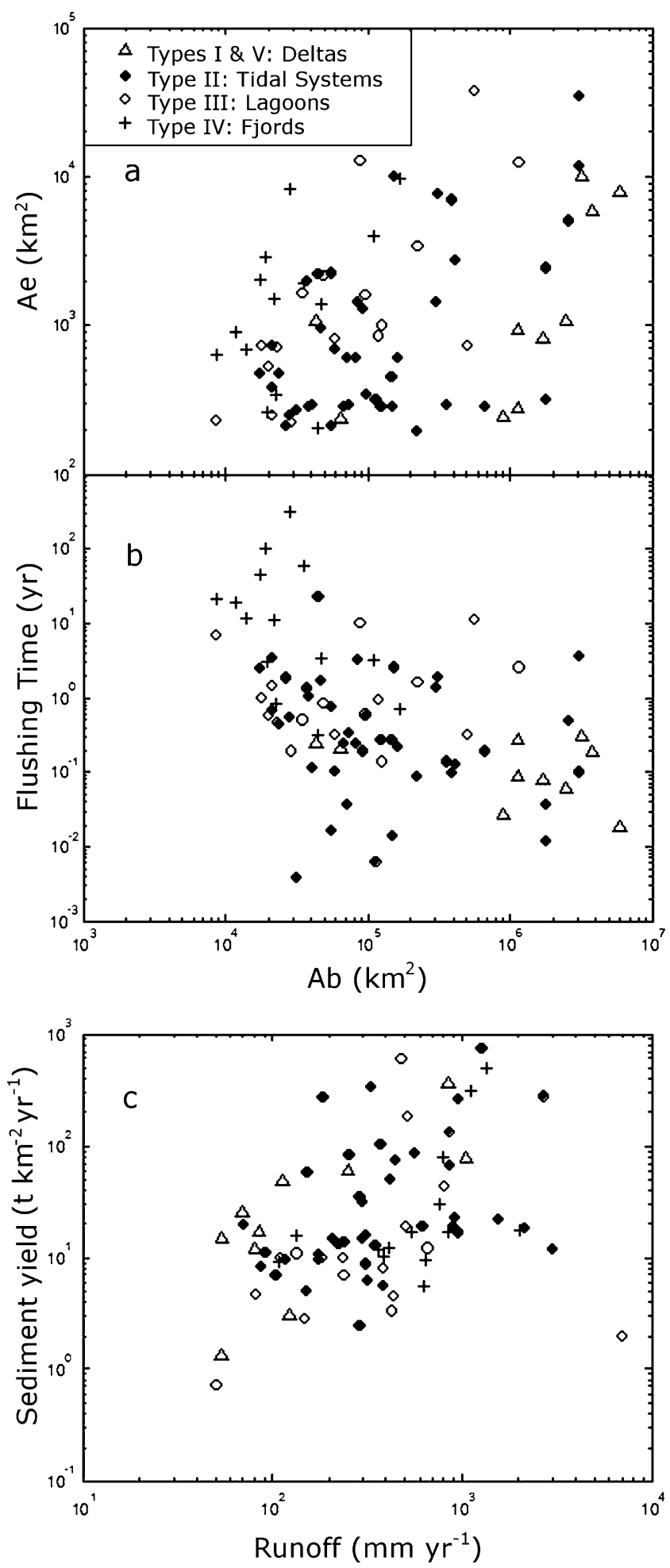

Fig. 7 Cluster analysis. Triangles represent deltas (type I), black filled circles represent tidal systems (type II), white filled circles represent lagoons (type III), and plus sign signs represent fjords (type IV). $\mathrm{Ae}=$ Estuarine surface area $\left(\mathrm{km}^{2}\right) ; \mathrm{Ab}=$ River watershed surface area $\left(\mathrm{km}^{2}\right)$
Fjords tend to range towards higher runoffs, whereas the overall variability for tidal systems is largest.

As our typology was established independently from the factors used in the cluster analysis, these observations serve as a validation of our approach and highlight the differences between the various factors responsible for the morphology of today's coastlines and their effects on the estuarine filtering of riverine inputs. The estuarine zone is clearly a variable filter. While the effects of human activities have not been included explicitly here, they certainly will have altered the filter efficiency for the different coastal types. Thus, for example, the filtering capacity of deltas likely has increased due to lower runoff linked to water extraction for irrigation, while the filter function of navigated estuaries likely has decreased.

\section{Limitations of Our Approach}

The geographic distribution of the coastal types is assessed based on different sources of information (Table 1), and most of the sources used serve to determine a single morphology or filtering type. The accuracy of the typology presented here depends on several factors, such as resolution and precision of source material, transfer of information from the source material (which often was not available in digital form) to the GIS and the decision to give one morphology priority over another in cases of overlap. In general, the highest uncertainty prevails when very coarse-scale maps are scanned or digitized from books and then geo-referenced in the GIS.

For some types, the uncertainty depends on the region, mainly due to the variety of sources available. Limitations of the typology are highest in cold climates, as the main source clearly delimiting the different types consists of a single map at coarse resolution (Gregory 1913), although other sources such as atlases or Google Earth were used as well. Furthermore, some areas in Siberia are morphologically defined as rias but might behave as a more passive filter system as they are frozen a large part of the year. Yet, the overall error induced by these uncertainties for the northern high latitudes is probably limited as coastal zones of the Arctic Ocean only receive $6 \%$ of the global sediment load and $7 \%$ of water discharge.

Indeed, some systems might change from one type to another in different seasons, depending on prevailing incoming river fluxes vs. coastal currents. In lowland areas such as in the Baltic, Black Sea and parts of the Mediterranean basin (e.g. North Adriatic), deltas and associated enclosed or semi-enclosed lagoons are more efficient filters depending on their connection with the open coast, their possibility of being flooded, the flooding occurrence etc. (Meybeck et al. 2004). In general, our classification describes a dominant present-day situation where the coastal zone is a very dynamic environment. 
The tidal systems of Europe are probably better defined than the same type in Asia. However, the Mediterranean coast of Europe is very heterogeneous, and at the $0.5^{\circ}$ resolution, the exact boundary of morphological variations is sometimes difficult to establish, while different smallscale features might show frequent overlap, especially for type I. Whereas the small deltas (type I) represent $73 \%$ of the sediment load discharged to the Mediterranean and Black Sea, they only represent a few percent of the global water (1\%) and sediment (7\%) fluxes. In Asia, the coasts of Japan, China and Indonesia have larger stretches of coast without distinct embayments or prominent features that were thus assigned to the 'type I' (small deltas) coasts. Here, the importance of type I is much larger: Small deltas receive $49 \%$ of the total sediment load and $29 \%$ of the water load of the coasts of Asia and still represent $29 \%$ and $8 \%$ of the global total sediment and water loads, respectively. As a consequence, we estimate that the general uncertainty is $<2 \%$ for systems with $>10$ or 15 river basin cells and around $15 \%$ for the smaller basins. This is not higher than other global scale attempts at a similar scale, such as the GlobalNEWS approach for land-based nutrient inputs (Seitzinger et al. 2005).

\section{Application: Estuarine Surface Area}

A first application of the typology consists of a re-estimate of the water surface area of the world's estuarine filters. In the early 1970s, a first attempt was made by Woodwell et al. (1973) to quantify the surface area of the world's estuaries. The area from their pioneering work continues to be used (e.g. Frankignoulle et al. 1998; Borges et al. 2005) and has not been updated since. Here we propose a revised figure, based on more extensive data on estuarine area for several regions of the world. Woodwell et al. (1973) define the term 'estuary' as systems being within the realm of tidal influence and upstream of the connection of the outside limit points. This definition essentially covers our definition of nearshore coastal zone filters, but Woodwell et al. (1973) also included large enclosed bodies of water such as the Baltic Sea. Woodwell et al. (1973) calculated a ratio of estuarine surface area per kilometre of coastline $\left(A_{\mathrm{e}} / C_{\mathrm{e}}\right)$ for a continent's known area and length of internal coastline, i. e. inside the line connecting outer limit points of internal systems. At that time, the only region with sufficient data coverage was the USA and the global extrapolation thus solely relied on a unique ratio established for the US coast, which was then extrapolated, using these ratios, by multiplying them with the known coastline length of the remaining continents.

Here, we use our typology to establish these ' $w$-ratios' (for 'Woodwell ratio') for each of the four types of coast representing our estuarine filters (types I-IV) and extrapo- late the results to the total world coastline (Antarctica and glaciated parts of Greenland were excluded). The data available for our study are from the conterminous USA without Alaska (Engle et al. 2007), the UK with the exclusion of Northern Ireland and Scotland (DEFRA 2008), Sweden (SMHI 2009) and Australia (Digby et al. 1998; AED 1999). Each of our coastal types is represented in at least two of these regions, and the total coastline used is $32,700 \mathrm{~km}$ ( $8 \%$ of the world). The coastline lengths were calculated at $0.5^{\circ}$ resolution. The use of the same method for the calculation of these lengths throughout our whole analysis ensures consistency between the values obtained.

The $w$-ratio obtained for each type may vary significantly for each region and generally increases with the number of the type of coast (I to IV; Table 5). The only exception to this rule is the very large $w$-ratio for US tidal systems, but this number includes large internal macrotidal bays such as the Chesapeake Bay $\left(10,072 \mathrm{~km}^{2}\right)$, accounting alone for $44 \%$ of the estuarine surface area of the country.

The weighted averages of the $w$-ratio for each type vary within one order of magnitude from small deltas (type I, $0.64 \mathrm{~km}^{2} / \mathrm{km}$ ) to lagoons (type III, $7.57 \mathrm{~km}^{2} / \mathrm{km}$ ). The global extrapolation leads to a fairly modest surface area for type I despite the longest coastline. Tidal systems (type II) and lagoons (type III) contribute equally with 0.28 and $0.25 \times 10^{6} \mathrm{~km}^{2}$, respectively. Fjords (type IV), having the second largest coastline and second-highest $w$-ratio, reach $0.46 \times 10^{6} \mathrm{~km}^{2}$, accounting for $43 \%$ of the total surface area of estuarine filters $\left(1.07 \times 10^{6} \mathrm{~km}^{2}\right)$. This number, however, should not be compared directly to Woodwell et al.'s. Indeed, in their work, out of $1.75 \times$ $10^{6} \mathrm{~km}^{2}, 0.38 \times 10^{6} \mathrm{~km}^{2}$ are salt marshes and another $0.42 \times 10^{6} \mathrm{~km}^{2}$ represent large bays, deltas and regional seas such as the Baltic Sea. Hence, the estuarine surface area in its most conservative sense amounts to less than $10^{6} \mathrm{~km}^{2}$. In addition, Woodwell et al. exclude surface areas north of $60^{\circ} \mathrm{N}$ latitude (except the Baltic Sea coastline), the west coast of Norway from $60^{\circ}$ to $70^{\circ} \mathrm{N}$ and the UK. This leaves out $30 \%$ of the world coastline. This implies, with our typology, a reduction of the fjords by $69 \%$ and the comparable estuarine surface area being only $0.64 \times 10^{6} \mathrm{~km}^{2}$ (33\% less than Woodwell et al.'s).

The main reason for this lower value is an inconsistency in the coastline length used by Woodwell et al. Coasts are known to possess a fractal property and their length varies with the scale of measurement (Mandelbrot 1967). In their study, Woodwell et al. used a coastline length estimated by the National Estuarine Pollution Study (USDOI 1970) for the USA. The $w$-ratios were then extrapolated to the coastline of entire continents of which the length was deduced from a single map (Man's Domain/A Thematic Atlas of the World). The smaller scale of measurement of the local studies of the USA led to an overestimation of the relative 
Table 5 Calculation of $w$-ratios (ratio of estuarine surface area per kilometre of coastline for a continent's known area and length of internal coastline from Woodwell et al. (1973)) for each type and estimation of the global surface area of estuarine filters

\begin{tabular}{|c|c|c|c|c|c|c|}
\hline Type & Country & Coastline $(\mathrm{km})$ & Surface $\left(\mathrm{km}^{2}\right)$ & $w$-ratio $\left(\mathrm{km}^{2} / \mathrm{km}\right)$ & Global Coastline $(\mathrm{km})$ & Surface extrapolation $\left(\mathrm{km}^{2}\right)$ \\
\hline \multirow[t]{3}{*}{ Type I } & USA & 1,458 & 1,298 & 0.89 & & \\
\hline & Australia & 7,091 & 4,179 & 0.59 & & \\
\hline & Total & 8,549 & 5,477 & 0.64 & 131,167 & 84,033 \\
\hline \multirow[t]{4}{*}{ Type II } & USA & 2,889 & 23,141 & 8.01 & & \\
\hline & Australia & 9,948 & 18,331 & 1.84 & & \\
\hline & UK & 3,350 & 7,362 & 2.20 & & \\
\hline & Total & 16,187 & 48,834 & 3.02 & 91,326 & 275,518 \\
\hline \multirow[t]{3}{*}{ Type III } & USA & 4,521 & 39,604 & 8.17 & & \\
\hline & Australia & 1,044 & 2,546 & 2.44 & & \\
\hline & Total & 5,565 & 42,150 & 7.57 & 33,286 & 252,112 \\
\hline \multirow[t]{3}{*}{ Type IV } & USA & 500 & 2,638 & 5.276 & & \\
\hline & Sweden & 2,576 & 10,624 & 4.12 & & \\
\hline & Total & 3,076 & 13,262 & 4.31 & 105,657 & 455,535 \\
\hline Grand total & & & & & & $1,067,198$ \\
\hline
\end{tabular}

contribution to the world's coastline $(5 \%$ in Woodwell et al.'s study without Alaska and $2.5 \%$ in our study, in agreement with official measurements of the CIA (CIA 2009), using a consistent $0.5^{\circ}$ scale for the worldwide coastline). In conclusion, our calculation provides the firstto our knowledge-exhaustive estimate for the global estuarine surface area.

\section{Conclusions/Perspectives}

In this work, we present the first spatially explicit, global typology for nearshore coastal systems which is GISbased and directly applicable for a wide range of purposes. Besides the update of the estimate for the global estuarine surface area presented here (re-estimated to $1.1 \times 10^{6} \mathrm{~km}^{2}$ instead of $1.4 \times 10^{6} \mathrm{~km}^{2}$ in Woodwell et al. (1973)), multiple additional applications have been shown, linking coastal types to incoming river fluxes or related population pressure. Other can be envisioned for riverine nutrient discharge (Seitzinger et al. 2005; Laruelle 2009). In view of all possible applications of this typology, our work is a major first step forward in the development of tools to describe the interface between continental and oceanic sciences at the global scale. Depending on the subject of interest, our current types may be further refined, for example, through the definition of subtypes or the addition of new types such as mangroves. A further extension of our typology will include the continental shelves (or distal zone) including the area of influence of the world's largest rivers (McKee et al. 2004; Laruelle et al. 2010).
Some future evolution of the typology itself might be expected based on changes in human and climate-induced changes in water regimes and sea level rise. For example, an increase of the sea level by $42-58 \mathrm{~cm}$ around 2,080 (Horton et al. 2008) will particularly affect small deltas and some lagoons. Yet, most morphological types such as drowned river valleys or fjords will not change.

Our surface areas are of direct use for biogeochemical budget calculations for the coastal zone (e.g. Borges et al. 2005; Laruelle et al. 2010) and modelling of nutrient cycling as done by Laruelle (2009) where a set of generic biogeochemical box models has been developed for each type and applied to estimate the estuarine retention of $\mathrm{N}$ and $\mathrm{P}$ from rivers. This typology-based modelling tool can provide an interface between spatially explicit global models for river discharge of nutrients (Seitzinger et al. 2005) and ocean global circulation models (Heinze and Maier-Reimer 1999; Heinze et al. 2003; Bernard et al. 2009).

Finally, several studies and generic models exist that apply to a particular type of estuarine setting (Valiela et al. 2004; Arndt 2008). These settings may be related to one of the present types of our typology, and hence, an explicit global distribution of the applicability domain would be available opening the door to potential global or regional extrapolations. The electronic supplementary material contains the GIS data, as well as high resolution versions of figure 5 . The authors can also be contacted for use of the typology data.

Acknowledgements This work was funded by Utrecht University (High Potential Project G-NUX) and the Netherlands Organisation for Scientific Research (NWO Vidi grant 864.05.004 and Van Gogh travel grant). We are greatly indebted to Sybil Seitzinger and Emilio 
Mayorga (Institute of Marine \& Coastal Sciences, Rutgers University, USA) for the communication of the merged Global-NEWS data sets.

Open Access This article is distributed under the terms of the Creative Commons Attribution Noncommercial License which permits any noncommercial use, distribution, and reproduction in any medium, provided the original author(s) and source are credited.

\section{References}

Allen, J.I., J. Blackford, J. Holt, R. Proctor, M. Ashworth, and J. Siddorn. 2001. A highly spatially resolved ecosystem model for the North West European Continental Shelf. Sarsia 86: 423-440.

Alongi, D.M. 1998. Coastal ecosystem processes. In Marine science series, ed. M.J. Kennish and P.L. Lutz. Boca Raton: CRC.

Arndt, S. 2008. Biogeochemical transformations and fluxes in redoxstratified environments: From the shallow coastal ocean to the deep subsurface. Ph.D. thesis, Utrecht, Utrecht University

Audry, S., G. Blanc, J. Schäfer, F. Guérin, M. Masson, and S. Robert. 2007. Budgets of $\mathrm{Mn}, \mathrm{Cd}$ and $\mathrm{Cu}$ in the macrotidal Gironde estuary (SW France). Marine Chemistry 107: 433-448. doi:10.1016/j.marchem.2007.09.008.

Aumont, O., J.C. Orr, P. Monfray, W. Ludwig, P. Amiotte-Suchet, and J.-L. Probst. 2001. Riverine-driven interhemispheric transport of carbon. Global Biogeochemical Cycles 15: 393-405.

Australian Estuarine Database 1999. A physical classification of Australian estuaries. http://www.precisioninfo.com/rivers_org/au/ library/nrhp/estuary_clasifn/. Accessed 1 May 2009.

Bartley, J.D., R.W. Buddemeier, and D.A. Bennett. 2001. Coastline complexity: A parameter for functional classification of coastal environments. Journal of Sea Research 46: 87-97.

Bernard, C.Y., H.H. Dür, C. Heinze, J. Segschneider, and E. MaierReimer. 2009. Contribution of riverine nutrients to the silicon biogeochemistry of the global ocean-a model study. Biogeosciences Discussions 6: 1091-1119.

Beusen, A.H.W., A.L.M. Dekkers, A.F. Bouwman, W. Ludwig, and J. Harrison. 2005. Estimation of global river transport of sediments and associated particulate C, N, and P. Global Biogeochemical Cycles 19: GB4S05. doi:10.1029/2005GB002453.

Borges, A.V., B. Delille, and M. Frankignoulle. 2005. Budgeting sinks and sources of $\mathrm{CO}_{2}$ in the coastal ocean: Diversity of ecosystems counts. Geophysical Research Letters 32: L14601. doi:10.1029/ 2005GL023053.

Buddemeier, R.W., S.V. Smith, D.P. Swaney, C.J. Crossland, and B.A. Maxwell. 2008. Coastal typology: An integrative "neutral" technique for coastal zone characterization and analysis. Estuarine, Coastal and Shelf Science 77: 197-205. doi:10.1016/j.ecss.2007.09.021.

Carter, R.W.G., and C.D. Woodroffe. 1994. In Coastal evolution, ed. R.W.G. Carter and C.D. Woodroffe. Cambridge: Cambridge University Press.

Castelao, R.M., and O.O. Moller Jr. 2006. A modeling study of Patos Lagoon (Brazil) flow response to idealized wind and river discharge: Dynamical analysis. Brazilian Journal of Oceanography 54: 1-17.

Chubarenko, B., and P. Margoński. 2008. The Vistula Lagoon. In Ecology of Baltic coastal waters; ecological studies, vol. 197, ed. P. Schiewer, 167-195. Berlin: Springer.

CIA. 2009. The World Factbook: https://www.cia.gov/library/publica tions/the-world-factbook/fields/2060.html. Accessed 1 May 2009.

Crossland, C.J., H.H. Kremer, H.J. Lindeboom, J.I. Marshall Crossland, and M.D.A. LeTissier. 2003. Coastal fluxes in the Anthropocene. Global change - the IGBP series. Berlin: Springer.

Da Cunha, L.C., E.T. Buitenhuis, C. Le Quéré, X. Giraud, and W. Ludwig. 2007. Potential impact of changes in river nutrient supply on global ocean biogeochemistry. Global Biogeochemical Cycles 21: GB4007. doi:10.1029/2006GB002718.

Dagg, M., R. Benner, S. Lohrenz, and D. Lawrence. 2004. Transformation of dissolved and particulate materials on continental shelves influenced by large rivers: Plume processes. Continental Shelf Research 24: 833-858.

Davis, R.A.J., and D.M. Fitzgerald. 2004. Beaches and coasts. Oxford: Blackwell.

Department for Environment, Food and Rural Affairs. 2008. The estuary guide http://www.estuary-guide.net/search/estuaries/. Accessed 18 Feb 2009.

Digby, M.J., P. Saenger, M.B. Whelan, D. McConchie, B. Eyre, N. Holmes, and D. Bucher. 1998. A physical classification of Australian Estuaries. Report prepared for the urban water research association of Australia by the centre for coastal management. Lismore: Southern Cross University.

Dolan, R., B. Hayden, and M. Vincent. 1975. Classification of coastal landform of the Americas. Zeitschrift für Geomorphologie, Supp. Bull. 22: 72-88.

Dürr, H.H., M. Meybeck, and S.H. Dürr. 2005. Lithologic composition of the Earth's continental surfaces derived from a new digital map emphasizing riverine material transfer. Global Biogeochemical Cycles 19: GB4S10. doi:10.1029/2005GB002515.

Dziganshin, G.F., and I.Y. Yurkova. 2001. Interannual variability of the river discharge into the North-western part of the Black Sea. In Systems of environmental control: Collected papers, ed. V.N. Eremeev, 267-272. Sevastopol: MHI NAS (in Russian).

Elliott, M., and D.S. McLusky. 2002. The need for definitions in understanding estuaries. Estuarine, Coastal and Shelf Science 55: $815-827$.

Engle, V.D., J.C. Kurtz, L.M. Smith, C. Chancy, and P. Bourgeois. 2007. A classification of U.S. estuaries based on physical and hydrologic attributes. Environmental Monitoring and Assessment 129: 397-412.

Ericson, J.P., C.J. Vörösmarty, S.L. Dingman, L.G. Ward, and M. Meybeck. 2006. Effective sea-level rise and deltas: Causes of change and human dimension implications. Global and Planetary Change 50: 63-82.

Fekete, B.M., C.J. Vörösmarty, and W. Grabs. 2002. High-resolution fields of global runoff combining observed river discharge and simulated water balances. Global Biogeochemical Cycles 16: 1042. doi:10.1029/1999GB001254.

Fleury, P., M. Bakalowicz, and G.D. Marsily. 2007. Submarine springs and coastal karst aquifers: A review. Journal of Hydrology 339: 79-92.

Ford, D.C., and P.W. Williams. 1989. Karst geomorphology and hydrology. London: Unwin Hyman.

Frankignoulle, M., G. Abril, A. Borges, I. Bourge, C. Canon, B. Delille, E. Libert, and J.-M. Théate. 1998. Carbon dioxide emission from European estuaries. Science 282: 434-436.

Gallo, M.N., and S.B. Vinzon. 2005. Generation of overtides and compound tides in Amazon estuary. Ocean Dynamics 55: 441448.

Gattuso, J.-P., M. Frankignoulle, and R. Wollast. 1998. Carbon and carbonate metabolism in coastal aquatic ecosystems. Annual Review of Ecology and Systematics 29: 405-434.

GEBCO. 2007. General bathymetric chart of the oceans. http://www. ngdc.noaa.gov/mgg/gebco/. Accessed 28 Dec 2006.

Google. 2009. Google earth. http://earth.google.com/. Accessed 1 May 2009.

Gordon, J.D.C., P.R. Boudreau, K.H. Mann, J.E. Ong, W.L. Silvert, S. V. Smith, G. Wattayakorn, F. Wulff, and T. Yanagi. 1996. LOICZ biogeochemical modelling guidelines. LOICZ reports \& studies, 5. Texel: LOICZ.

Gregory, J.W. 1913. The nature and origin of fiords. London: John Murray. 
Grelowski, A., M. Pastuszak, S. Sitek, and Z. Witek. 2000. Budget calculations of nitrogen, phosphorus and BOD5 passing through the Oder estuary. Journal of Marine Systems 25: 221-237.

Harris, P.T., A.D. Heap, S.M. Bryce, R. Porter-Smith, D.A. Ryan, and D.T. Heggie. 2002. Classification of Australian clastic coastal depositional environments based upon a quantitative analysis of wave, tidal, and river power. Journal of Sedimentary Research 72: 858-870.

Harrison, P.J., N. Khan, K. Yin, M. Saleem, N. Bano, M. Nisa, S.I. Ahmed, N. Rizvi, and F. Azam. 1997. Nutrient and phytoplankton dynamics in two mangrove tidal creeks of the Indus River delta, Pakistan. Marine Ecology Progress Series 157: 13-19.

Hayes, M.O. 1979. Barrier island morphology as a function of wave and tide regime. In Barrier islands from the Gulf of St. Lawrence to the Gulf of Mexico, ed. S.P. Leatherman, 1-29. New York: Academic.

Heinze, C., and E. Maier-Reimer. 1999. The Hamburg oceanic carbon cycle circulation model version "HAMOCC2s" for long time integrations. Technical Report 20. Hamburg: Deutsches Klimarechenzentrum, Modellberatungsgruppe.

Heinze, C., A. Hupe, E. Maier-Reimer, N. Dittert, and O. Ragueneau. 2003. Sensitivity of the marine biospheric Si cycle for biogeochemical parameter variations. Global Biogeochemical Cycles 17: 3. doi:10.1029/2002GB001943.

Herak, M., and V.T. Stringfield. 1972. Karst-important karst regions of the Northern Hemisphere. Amsterdam: Elsevier.

Horton, R., C. Herweijer, C. Rosenzweig, J. Liu, V. Gornitz, and A.C. Ruane. 2008. Sea level rise projections for current generation CGCMs based on the semi-empirical method. Geophysical Research Letters 35: L02715. doi:10.1029/2007GL032486.

Ivanov, V.V. 1991. The estimation of water reserves in the Arctic estuaries with closed estuarine systems. Problems of Arctic and Antarctic 66: 224-238 (In Russian).

Kelletat, D.H. 1995. Atlas of coastal geomorphology and zonality. Journal of Coastal Research, 13(special issue):286 pp

Kempe, S. 1988. Estuaries - their natural and anthropogenic changes. In Scales and global change. SCOPE, ed. T. Rosswall, R.G. Woodmansee, and P.G. Risser, 251-285. New York: Wiley.

Laruelle, G.G. 2009. Quantifying nutrient cycling and retention in coastal waters at the global scale, $\mathrm{Ph} \mathrm{D}$ dissertation, Utrecht University.

Laruelle, G.G., H.H. Dürr, C.P. Slomp, and A.V. Borges. 2010. Reevaluation of air-water exchange of $\mathrm{CO} 2$ in the global coastal ocean using a spatially-explicit typology. Geophysical Research Letters 37: L15607. doi:10.1029/2010GL043691.

Laval, B.E., J. Imberger, and A.N. Findikakis. 2005. Dynamics of a large tropical lake: Lake Maracaibo. Aquatic Sciences-Research Across Boundaries 67: 337-349. doi:10.1007/s00027-005-0778-1.

Lohrenz, S.E., D.G. Redalje, P.G. Verity, C. Flagg, and K.V. Matulewski. 2002. Primary production on the continental shelf off Cape Hatteras, North Carolina. Deep-Sea Research II 49: 4479-4509.

Mandelbrot, B. 1967. How long is the coast of Britain? Statistical selfsimilarity and fractional dimension. Science, New Series 156: 636-638. doi:10.1126/science.156.3775.636.

Marín, V.H., L.E. Delgado, and P. Bachmann. 2008. Conceptual PHES-system models of the Aysén watershed and fjord. (Southern Chile): Testing a brainstorming strategy. Journal of Environmental Management 88: 1109-1118.

McKee, B.A., R.C. Aller, M.A. Allison, T.S. Bianchi, and G.C. Kineke. 2004. Transport and transformation of dissolved and particulate materials on continental margins influenced by major rivers: Benthic boundary layer and seabed processes. Continental Shelf Research 24: 899-926.

Meybeck, M., and H.H. Dürr. 2009. Cascading filters of river material from headwaters to regional seas: The European example. In Watersheds, Bays, and Bounded Seas - the science and management of semi-enclosed marine systems, SCOPE series 70, ed. E. R. Urban Jr., B. Sundby, P. Malanotte-Rizzoli, and J.M. Melillo, 115-139. Washington: Island Press.
Meybeck, M., H.H. Dürr, J. Vogler. 2004. River/coast relations in European regional seas. Eurocat WP 5.3. Report.

Meybeck, M., H.H. Dürr, and C.J. Vörosmarty. 2006. Global coastal segmentation and its river catchment contributors: A new look at land-ocean linkage. Global Biogeochemical Cycles 20: GB1S90. doi: $10.1029 / 2005$ GB002540.

Moll, A., and G. Radach. 2003. Review of three-dimensional ecological modelling related to the North Sea shelf system part 1: Models and their results. Progress in Oceanography 57: 175-217.

Monbet, Y. 1992. Control of phytoplankton biomass in estuaries a comparative analysis of microtidal and macrotidal estuaries. Estuaries 15: 563-571.

Mortazavi, B., R.L. Iverson, W. Huang, F.G. Lewis, and J.M. Caffrey. 2000. Nitrogen budget of Apalachicola Bay, a bar-built estuary in the northeastern Gulf of Mexico. Marine Ecology Progress Series 195: 1-14.

NASA. 2006. SeaWiFS. http://oceancolor.gsfc.nasa.gov/SeaWiFS/ BACKGROUND/. Accessed 12 Apr 2007.

New York Times. 1992. Times atlas of the world: Comprehensive edition, 9th ed. New York: New York Times.

Nixon, S.W., J.W. Ammerman, L.P. Atkinson, V.M. Berounsky, G. Billen, W.C. Boicourt, W.R. Boynton, T.M. Church, D.M. Ditoro, R. Elmgren, J.H. Garber, A.E. Giblin, R.A. Jahnke, N.J. P. Owens, M.E.Q. Pilson, and S.P. Seitzinger. 1996. The fate of nitrogen and phosphorus at the land-sea margin of the North Atlantic Ocean. Biogeochemistry 3: 141-180.

Rabouille, C., F.T. Mackenzie, and L.M. Ver. 2001. Influence of the human perturbation on carbon, nitrogen, and oxygen biogeochemical cycles in the global coastal ocean. Geochimica et Cosmochimica Acta 65: 3615-3641.

Schwartz, M.L. 2005. Encyclopedia of coastal science. Dordrecht: Springer.

Seitzinger, S.P., J.A. Harrison, E. Dumont, A.H.W. Beusen, and F.B. A. Bouwman. 2005. Sources and delivery of carbon, nitrogen, and phosphorus to the coastal zone: An overview of global Nutrient Export from Watersheds (NEWS) models and their application. Global Biogeochemical Cycles 19: GB4S01. doi:10.2029/2005GB002606.

Selvam, V. 2003. Environmental classification of mangrove wetlands of India. Current Science 84: 757-765.

Sheldon, J.E., and M. Alber. 2006. The calculation of estuarine turnover times using freshwater fraction and tidal prism models: A critical evaluation. Estuaries and Coasts 29: 133-146.

Slomp, C.P., and P. Van Cappellen. 2004. Nutrient inputs to the coastal ocean through submarine groundwater discharge: Controls and potential impact. Journal of Hydrology 295: 64-86.

SMHI. 2009. Swedish Oceanographic Data Center, http://www.smhi. se/cmp/jsp/polopoly.jsp?d=5431\&l=sv. Accessed 1 May 2009.

Smith, W.H.F., and D.T. Sandwell. 1997. Global seafloor topography from satellite altimetry and ship depth soundings, version $9.1 \mathrm{~b}$. http://topex.ucsd.edu/marine_topo/. Accessed 20 Dec 2007.

Smith, S.V., and J.T. Hollibaugh. 1993. Coastal metabolism and the oceanic carbon balance. Reviews of Geophysics 31: 75-89.

Solidoro, C., R. Pastres, and G. Cossarini. 2005. Nitrogen and plankton dynamics in the lagoon of Venice. Ecological Modelling 184: $103-124$.

Sørnes, T.A., and D.L. Aksnes. 2006. Concurrent temporal patterns in light absorbance and fish abundance. Marine Ecology Progress Series 325: 181-186.

Stewart, J.S. 2000. Tidal energetics: Studies with a barotropic model. Ph.D. thesis, Boulder: University of Colorado.

Sweeting, M.M. 1972. Karst landforms. London: Macmillan.

Syvitski, J.P.M., D.C. Burrell, and J.M. Skei. 1987. Fjords: processes and products. New York: Springer.

Talaue-McManus, L.T., S.V. Smith, and R.W. Buddemeier. 2003. Biophysical and socio-economic assessments of the coastal zone: 
The LOICZ approach. Ocean and Coastal Management 46: 323333.

Tolmazin, D. 1985. Economic impact on the riverine-estuarine environment of the USSR: The Black Sea basin. GeoJournal 11: 137-152. doi:10.1007/BF00212915.

U.S. Department of Commerce, National Oceanic and Atmospheric Administration, National Geophysical Data Center. 2006. 2minute Gridded Global Relief Data (ETOPO2v2). http://www. ngdc.noaa.gov/mgg/fliers/06mgg01.html. Accessed 26 Dec 2008.

USDOI. 1970. The national estuarine pollution study. Report of the Secretary of Interior to the U.S. Congress pursuant to Public Law 89-753, the Clean Water Restoration Act of 1966. Document No. 91-58. Washington, DC.

Vafeidis, A.T., R.J. Nicholls, L. McFadden, R.S.J. Tol, J. Hinkel, T. Spencer, P.S. Grashoff, G. Boot, and R.J.T. Klein. 2008. A new global coastal database for impact and vulnerability analysis to sea-level rise. Journal of Coastal Research 24: 917-924.

Valiela, I., S. Mazzilli, J.L. Bowen, K.D. Kroeger, M.L. Cole, G. Tomasky, and T. Isaji. 2004. ELM, an estuarine nitrogen loading model: Formulation and verification of predicted concentrations of dissolved inorganic nitrogen. Water, Air, and Soil Pollution 157: 365-391.

Vörösmarty, C.J., B.M. Fekete, M. Meybeck, and R.B. Lammers. 2000a. The global system of rivers: Its role in organizing continental land mass and defining land-to-ocean linkages. Global Biogeochemical Cycles 14: 599-621.

Vörösmarty, C.J., B.M. Fekete, M. Meybeck, and R.B. Lammers. 2000b. Geomorphometric attributes of the global system of rivers at 30-minute spatial resolution. Journal of Hydrology 237: $17-39$.

Vörösmarty, C.J., P. Green, J. Salisbury, and R.B. Lammers. 2000c. Global water resources: Vulnerability from climate change and population growth. Science 289: 284-288.

Walling, D.E., and D. Fang. 2003. Recent trends in the suspended sediment loads of the world's rivers. Global and Planetary Change 39: 111-126.

Walsh, J.J. 1988. On the nature of continental shelves. San Diego: Academic.

Walsh, J.P., and C.A. Nittrouer. 2009. Understanding fine-grained river-sediment dispersal on continental margins. Marine Geology 263: 34-45.

Wong, M.H., and K.C. Cheung. 2000. Pearl River Estuary and Mirs Bay, South China. In Estuarine systems of the South China Sea Region: Carbon, nitrogen and phosphorus fluxes. LOICZ reports and studies 14, ed. V. Dupra, S.V. Smith, J.I. Marshall Crossland, and C.J. Crossland, 7-16. Texel: LOICZ.

Woodwell, G.M., P.H. Rich, and C.A.S. Hall. 1973. Carbon in estuaries. In Carbon and the biosphere, ed. G.M. Woodwell and E.V. Pecan, 221-240. Virginia: Springfield. 